\title{
Mechanism of Enhanced Fibroblast Arachidonic Acid Metabolism by Mononuclear Cell Factor
}

Phyllis Jonas Whiteley and Philip Needleman

Department of Pharmacology, Washington University Medical

School, St. Louis, Missouri 63110

A with an infiltration of mononuclear cells, fibroblast proliferation, and elevated levels of prostaglandin (PG) $\mathrm{E}_{2}$. Mononuclear cell conditioned factor (MNCF) medium $(5 \%)$ stimulated a 100 -fold increase in basal human dermal fibroblast $\mathrm{PGE}_{2}$ release over $48 \mathrm{~h}$ as compared with fibroblasts that were incubated with control medium (conditioned medium prepared without cells). The MNCF-induced $\mathrm{PGE}_{2}$ production was suppressed by protein synthesis inhibitors. Fibroblasts pretreated with control medium released $\mathrm{PGE}_{2}$ only modestly in response to $1 \mathrm{nM}$ bradykinin for $1 \mathrm{~h}$ (basal, $50 \pm 7 \mathrm{pg} \mathrm{PGE}_{2} / \mu \mathrm{g}$ protein; stimulated, $104 \pm 12 \mathrm{pg} \mathrm{PGE}_{2} / \mu \mathrm{g}$ protein), whereas cells that had been pretreated with $\mathrm{MNCF}$ showed a greatly facilitated bradykinin-induced release of $\mathrm{PGE}_{2}$. (basal, $297 \pm 59 \mathrm{pg} \mathrm{PGE}_{2} / \mu \mathrm{g}$ protein; stimulated, $866 \pm 85 \mathrm{pg} \mathrm{PGE}_{2} / \mu \mathrm{g}$ protein). The exaggerated agonist response is not specific for bradykinin because plateletderived growth factor elicits a similar response. Exogenous arachidonic acid conversion to $\mathrm{PGE}_{2}$ was also facilitated (two- to threefold) by MNCF pretreatment as compared with control. Both the enhanced agoniststimulated and exogenous arachidonic acid-induced $\mathrm{PGE}_{2}$ release from the MNCF pretreated cells were inhibited by actinomyin $\mathrm{D}$ or cycloheximide. A kinetic study of microsomal cyclooxygenase prepared from fibroblasts pretreated with MNCF showed a threefold increase in the maximum velocity $\left(V_{\max }\right)$ but the same Michaelis constant $\left(K_{m}\right)$ as control-treated cells. This augmented arachidonic acid metabolism and subsequent enhanced $\mathrm{PGE}_{2}$ production may play an important role

\footnotetext{
Address correspondence to Dr. Needleman.

Received for publication 25 May 1984 and in revised form 20 August 1984.
}

J. Clin. Invest.

(c) The American Society for Clinical Investigation, Inc.

$0021-9738 / 84 / 12 / 2249 / 05 \quad \$ 1.00$

Volume 74, December 1984, 2249-2253 in macrophage-fibroblast interactions at sites of inflammation.

\section{Introduction}

Chronic tissue inflammation is generally associated with an infiltration of mononuclear cells and a fibrogenesis. Monocytes, when stimulated, release a whole spectrum of products, including arachidonic acid (AA) ${ }^{1}$ metabolites (1), complement components (2), and monokines (3), which elicit a large number of responses on local vasculature, immune processes, and various target cell functions. Endogenous mediators of inflammation, such as bradykinin and prostaglandins (PG), are derived from the injured tissue. Bradykinin is formed by cleavage of kininogen by kallikrein (4), and during the inflammatory reaction acts as a vasodilator (5) and increases vascular permeability (6), thereby contributing to the edema. Bradykinin also elicits PG release from various intact organ systems (7) as well as different cell types such as fibroblasts (8) and endothelial cells (9). Chronic inflammation has been associated with elevated levels of $\mathrm{PGE}_{2}$ at the site of injury. $\mathrm{PGE}_{2}$ is a vasodilator (10), enhances vascular permeability (11), and plays a role in the regulation of the immune response by modulating $\mathrm{T}$ lymphocyte proliferation, macrophage cytotoxicity, and lymphokine production (12).

Macrophages seem to actively modulate fibroblast proliferation and PG production (13). Human peripheral blood mononuclear cells in vitro release a variety of factors over a 72-h period into the culture medium. The supernatant medium from these cultures contains a factor that results in a marked (50-200-fold) stimulation of $\mathrm{PGE}_{2}$ biosynthesis from dermal fibroblasts (13), gingival fibroblasts (14), synovial cells (15), and lung fibroblasts (16). In some models, such as pulmonary fibrosis, the monocyte-conditioned medium suppresses fibroblast proliferation by stimulation of $\mathrm{PGE}_{2}$ production (16). The rabbit hydronephrotic kidney (HNK), a model of renal injury, exhibits histological evidence of a macrophage invasion

1. Abbreviations used in this paper: $\alpha \mathrm{MO}$, minimal essential medium alpha; AA, arachidonic acid; CLK, contralateral kidney; HNK, hydronephrotic kidney; MNCF, mononuclear cell factor; PDGF, plateletderived growth factor; PG, prostaglandin. 
and fibroblast proliferation, and is associated with a greatly exaggerated renal AA metabolism in response to stimulation with bradykinin (17). An in vitro cell culture derived from HNK cortical explants contained macrophages and fibroblasts and elicited a profound $\mathrm{PGE}_{2}$ synthesis in response to bradykinin and exogenous AA (18). Since mononuclear-cell conditioned medium stimulates basal fibroblast $\mathrm{PGE}_{2}$ production, we reasoned that the conditioned medium might also alter agonist-stimulated fibroblast $\mathrm{PGE}_{2}$ production. This paper addresses the mechanism by which mononuclear cell factor alters both basal- and agonist-stimulated fibroblast AA metabolism.

\section{Methods}

Cell cultures. Human dermal fibroblasts were obtained from the American Type Cell Culture Collection, Rockville, MD (CRL 1445). Cells were maintained in $150 \mathrm{~cm}^{2}$ tissue culture flasks (Corning Glassworks, Corning, NY) in minimal essential medium alpha (Basic Cancer Center, Washington University, St. Louis, MO), 15 mM Hepes buffer, L-glutamine $(2 \mathrm{mM})$, penicillin $(100 \mathrm{U} / \mathrm{ml})$, and streptomycin $(100 \mu \mathrm{g} / \mathrm{ml}$ ) (termed $\alpha \mathrm{MO}$ ) supplemented with $10 \%$ fetal calf serum (KC Biological Inc., Lenexa, KS). Cells were fed twice weekly, passaged at confluence, and used for experiments between the 5th and 20th subpassage in culture.

Supernatant preparation. Human peripheral blood mononuclear cells from heparinized venous blood of normal volunteers were prepared by the method of Böyum (19). Basically, the mononuclear cells were isolated on a Ficoll-Hypaque density centrifugation gradient (Histopaque; Sigma Chemical Co., St. Louis, MO). The mononuclear cellenriched interface fraction was then washed three times with $\alpha \mathrm{MO}$. For production of supernatant, mononuclear cells $\left(5 \times 10^{5} / \mathrm{ml}\right)$ were cultured for $72 \mathrm{~h}$ at $37^{\circ} \mathrm{C}$ in a $5 \% \mathrm{CO}_{2} / 95 \%$ air humidified atmosphere in $\alpha \mathrm{MO}$ supplemented with $10-20 \%$ fetal calf serum. To terminate cultures, tubes of the conditioned medium were centrifuged for 10 min at $1,000 \mathrm{rpm}$. The supernatant was retained and passed through a $2-\mu \mathrm{m}$ filter (Millipore Corp., Bedford, MA). Cell-free supernatant, which is termed mononuclear cell factor (MNCF), was stored at $-20^{\circ} \mathrm{C}$ until used. Control medium was prepared in the same way as MNCF but without any mononuclear cells.

Assay for MNCF-induced $P G E_{2}$ production. Fibroblast cultures were harvested by brief exposure to trypsin $(0.25 \%)$, which was washed off the cells by centrifugation. The cells were resuspended at $10^{5}$ cells/ $\mathrm{ml}$ in $\alpha \mathrm{MO}$. Equal $100-\mu \mathrm{l}$ volumes of the fibroblast suspension and of diluted conditioned medium (10\%) were added to quadruplicate wells of 96-well flat-bottomed tissue culture plates (Costar, Cambridge, MA) and cultured for $48 \mathrm{~h}$ at $37^{\circ} \mathrm{C}$ in a $5 \% \mathrm{CO}_{2} / 95 \%$ air humidified atmosphere. At the termination of the culture, the medium was removed and stored at $-20^{\circ} \mathrm{C}$ until assayed for $\mathrm{PGE}_{2}$ by radioimmunoassay (RIA).

Assay for agonist-induced $P G E_{2}$ production. Fibroblasts were pretreated with conditioned medium for $48 \mathrm{~h}$. Then the medium was removed, cells were washed three times with $\alpha \mathrm{MO}$, and the appropriate agonist in $\alpha \mathrm{MO}$ was added back to the cultures for an additional hour. To terminate the incubation, the medium was removed and stored at $-20^{\circ} \mathrm{C}$ until assayed for $\mathrm{PGE}_{2}$ by RIA. Data shown are of representative experiments and are expressed as mean \pm SEM of quadruplicate wells. Experiments were repeated at least three times.
Protein determination. Cells from all experiments were washed three times with phosphate-buffered saline $(50 \mathrm{mM}$ potassium phosphate). $200 \mu \mathrm{l}$ of $0.62 \mathrm{~N} \mathrm{NaOH}$ was added to each well to solubilize the protein. The protein concentration of the cells was determined fluorometrically with fluorescamine using bovine serum albumin as a standard. Proteins generally ranged from 2 to $4 \mu \mathrm{g}$ protein/well.

Preparation of microsomes. Cells $\left(5 \times 10^{6}\right.$ cells $/ 150 \mathrm{~cm}^{2} \mathrm{~T}$-flask) were pretreated with either control or MNCF medium for $48 \mathrm{~h}$. The cells were then washed, scraped from the flask, and centrifuged in $\alpha \mathrm{MO}$ for $10 \mathrm{~min}$ at $1,000 \mathrm{rpm}$. The cells were resuspended in $1 \mathrm{ml}$ of $50 \mathrm{mM}$ Tris buffer ( $\mathrm{pH} 7.8$ ) containing $1 \%$ bovine serum albumin and $10 \mathrm{mM}$ EGTA. The suspension was sonicated for $30 \mathrm{~s}$ in a Cell Disruptor 350 (Sonifier) at pulsed $40 \%$ duty cycle, three output control. Microscopic examination revealed that the cells were completely broken apart. The disrupted cells were centrifuged at $8,000 \mathrm{~g}$ for 15 $\mathrm{min}$, and the resulting supernatant was centrifuged at $100,000 \mathrm{~g}$ for $60 \mathrm{~min}$. The pellets obtained were washed with $50 \mathrm{mM}$ Tris buffer $(\mathrm{pH} 7.8)$ and $1 \mathrm{mM}$ EGTA. The pellet was then resuspended in a glass homogenizer with $500 \mu \mathrm{l}$ of the $50 \mathrm{mM}$ Tris buffer (pH 7.8), $1 \mathrm{mM}$ EGTA.

Kinetic analysis of microsomes. The time course for microsomal conversion of AA to $\mathrm{PGE}_{2}$ (as detected by RIA) indicated the conversion to be linear for $30 \mathrm{~min}$. The microsomes were incubated with various concentrations of $\mathrm{AA}(0-30 \mu \mathrm{M})$ for $10 \mathrm{~min}$ at $37^{\circ} \mathrm{C}$ in the presence of $1.2 \mathrm{mM}$ epinephrine and $1.0 \mathrm{mM}$ reduced glutathione. The reaction was terminated on ice and then stored at $-20^{\circ} \mathrm{C}$ until assayed for $\mathrm{PGE}_{2}$. For control purposes, some microsomes were preincubated with indomethacin $(5 \mu \mathrm{g} / \mathrm{ml})$ for $20 \mathrm{~min}$ on ice.

$R I A$ of $P G E_{2} . P E_{2}$ was analyzed with rabbit antiserum as previously described (20). The cross-reactivity at 50\% displacement of other PGs with the antiserum is as follows: 6-keto- $\mathrm{PGF}_{1} \alpha, 0.39 \% ; \mathrm{PGF}_{2} \alpha, 0.04 \%$; $\mathrm{TxB}_{2}, 0.009 \%$.

\section{Results}

Effect of MNCF on basal fibroblast PGE accumulation. When fibroblasts $\left(10^{4}\right.$ cells/well) were incubated with $5 \% \mathrm{MNCF}$ (determined to be an optimal dose; data not shown) or $5 \%$ control medium for $48 \mathrm{~h}$ (Table I), there was approximately a 100-fold stimulation of $\mathrm{PGE}_{2}$ from MNCF-treated cells. The MNCF-induced $\mathrm{PGE}_{2}$ production was completely abolished by ibuprofen, a cyclooxygenase inhibitor. To determine if the exaggerated $\mathrm{MNCF}$-induced fibroblast $\mathrm{PGE}_{2}$ release was dependent upon protein synthesis, the fibroblasts were incubated simultaneously with the conditioned medium and protein synthesis inhibitors (Table I). Both actinomycin D and cycloheximide at least partially $(50-70 \%)$ abolished the MNCFinduced fibroblast $\mathrm{PGE}_{2}$ release. The effect of the protein synthesis inhibitors was not due to a loss of cell viability, since there was no change or perhaps a slight enhancement of $\mathrm{PGE}_{2}$ in the control treated cells, and the adherent fibroblasts excluded trypan blue. Higher doses of actinomycin $D$ and cycloheximide nonspecifically inhibited cyclooxygenase, as determined by exogenous AA conversion, and in some instances were toxic to the cells. Therefore, even though higher doses of the inhibitors provided a more complete inhibition of the response, 
Table I. Effect of MNCF on Basal Fibroblast PGE $E_{2}$ Production

\begin{tabular}{lccl}
\hline & $5 \%$ Control & $5 \%$ MNCF \\
\hline & \multicolumn{4}{c}{$p g P G E_{2} / \mu g$ protein } \\
No treatment & $14 \pm 2(9)$ & $1,694 \pm 93 \quad(14)$ \\
Ibuprofen $(10 \mu \mathrm{M})$ & $9 \pm 1(6)$ & $69 \pm 6 \quad(5)$ \\
Actinomycin $(40 \mathrm{nM})$ & $74 \pm 5(3)$ & $519 \pm 18 \quad(3)$ \\
Cycloheximide $(36 \mathrm{nM})$ & $16 \pm 2(3)$ & $798 \pm 150(3)$
\end{tabular}

Fibroblasts $\left(10^{4} /\right.$ well) were treated for $48 \mathrm{~h}$ and assayed for $\mathrm{PGE}_{2}$ as described in Methods. Data are expressed as the mean \pm SEM of the number of determinations from separate experiments indicated in parentheses.

we chose the lowest dose of inhibitor, in which there were no deleterious effects to the cells.

Effect of MNCF on agonist-induced fibroblast $P G E_{2}$ release. Since MNCF had such a profound effect on basal fibroblast $\mathrm{PGE}_{2}$ release, we wished to determine if MNCF could also enhance agonist-induced fibroblast $\mathrm{PGE}_{2}$ release. Cells were pretreated with either $5 \%$ control medium or $5 \% \mathrm{MNCF}$ for $48 \mathrm{~h}$, washed three times as described in Methods, and then incubated with the appropriate agonist for $1 \mathrm{~h}$. In a 1-h incubation without any agonist, conditioned medium, or serum, there is more fibroblast $\mathrm{PGE}_{2}$ production from MNCF-pretreated fibroblasts than from control-treated fibroblasts (Fig. 1, $A$ and $B$ ). A bradykinin dose-response curve is shown in Fig. $1 A$. Cells that had been pretreated with control medium showed only a modest response to bradykinin, whereas MNCFpretreated cells showed a greatly enhanced response to bradykinin with a dose as low as $1 \mathrm{nM}$ bradykinin. To determine if this facilitated response was specific for bradykinin or if in fact
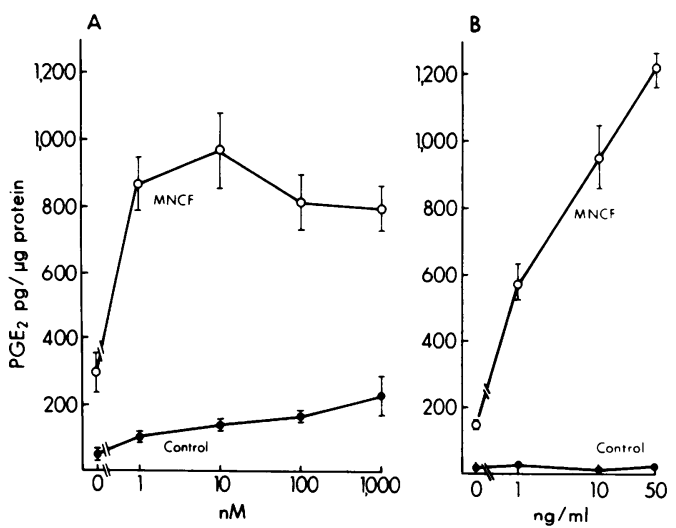

Figure 1. Effect of MNCF on hormonally induced fibroblast $\mathrm{PGE}_{2}$ release. Fibroblasts pretreated with $5 \%$ control medium $(\bullet)$ or $5 \%$ MNCF $(O)$ were incubated with varying doses of bradykinin $(A)$ or PDGF $(B)$, and PGE $_{2}$ release was assayed by RIA. All MNCF-treated cell values are statistically different $(P \leq 0.01)$ from control treated cells. other agonists were also affected, we incubated the cells with platelet-derived growth factor (PDGF). PDGF has been shown for some fibroblasts (21) to elicit a $\mathrm{PGE}_{2}$ response, although our control pretreated cells did not respond. However, MNCFpretreated cells showed a rather substantial release of $\mathrm{PGE}_{2}$ in response to PDGF that was dose dependent (Fig. $1 B$ ).

Since this altered peptide-induced fibroblast $\mathrm{PGE}_{2}$ release was quite dramatic, we explored the mechanism by which this might occur. Exogenous AA at varying doses was incubated with cells (Fig. 2) that had been pretreated with conditioned medium in the same manner as with bradykinin and PDGF. Fibroblasts pretreated with control medium were able to convert AA to $\mathrm{PGE}_{2}$ quite readily. However, for a fixed dose of AA, MNCF-pretreated cultures converted AA to significantly more $\mathrm{PGE}_{2}$, indicative of more cyclooxygenase activity.

Effect of MNCF on fibroblast microsomal cyclooxygenase activity. In whole cells, exogenous AA is readily incorporated to the phospholipid membrane, and therefore, assessment of cyclooxygenase activity is difficult to quantitate. To specifically address whether MNCF was altering fibroblast cyclooxygenase activity, we prepared fibroblast microsomes after a 48-h conditioned medium pretreatment. Fibroblast cyclooxygenase activity was quantitatively determined by RIA of the $\mathrm{PGE}_{2}$ produced from the conversion of AA by microsomes. The reaction rates of microsomes prepared with $\mathrm{AA}$ as substrate were linear for $30 \mathrm{~min}$ of incubation at $37^{\circ} \mathrm{C}$. Thus, the initial rate comparisons were studied at $10 \mathrm{~min}$. Although the Michaelis constants $\left(K_{\mathrm{m}}\right.$ 's) for the fibroblasts' cyclooxygenase under both conditions were similar (Table II), the maximum velocity $\left(V_{\max }\right)$ for MNCF-pretreated fibroblasts' cyclooxygenase was about threefold greater than the $V_{\max }$ for control treated cells.

Effect of protein synthesis inhibitors on agonist-induced $P G E_{2}$ release. To determine if the facilitated agonist-induced $\mathrm{PGE}_{2}$ release was protein synthesis dependent, we performed the following experiment. Fibroblasts were grown in the presence of 5\% control medium or 5\% MNCF with and without protein synthesis inhibitors (Table I). The medium was then

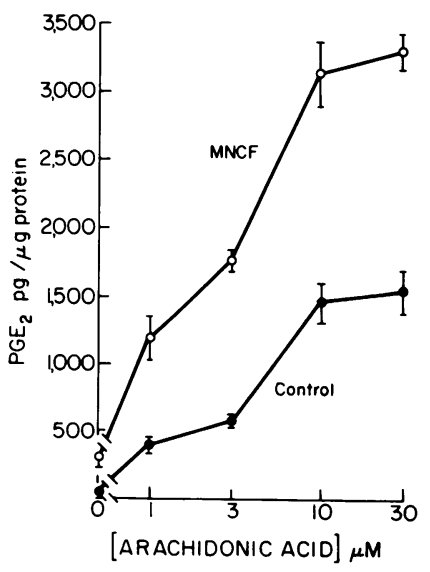

Figure 2. Effect of MNCF on exogenous AA conversion by fibroblasts. Fibroblasts pretreated with $5 \%$ control medium (•) or $5 \%$ MNCF (0) were incubated with varying doses of $\mathrm{AA}$, and $\mathrm{PGE}_{2}$ release was measured by RIA. All MNCF-treated cell values are statistically different $(P \leq 0.01)$ from control treated cells. 
Table II. Effect of MNCF on

Microsomal Cyclooxygenase Activity

\begin{tabular}{llll}
\hline & $V_{\max }$ & $K_{\mathrm{m}}$ & $V_{\max }$ \\
\hline & $f m o l ~ P G E_{2} / \mu g / m i n$ & $\mu M$ & $M N C F /$ control \\
Experiment 1 & & & \\
Control & 7.5 & 1.3 & 2.6 \\
MNCF & 19.3 & 1 & \\
Experiment 2 & & & \\
Control & 4.0 & .9 & 3.1 \\
MNCF & 12.5 & 1.6 & \\
& & &
\end{tabular}

Effect of MNCF on fibroblast cyclooxygenase activity. Microsomes were prepared from fibroblasts $\left(5 \times 10^{6}\right.$ cells/flask) cultured for $48 \mathrm{~h}$ with $5 \%$ control medium or $5 \% \mathrm{MNCF}$ as described in Methods. Varying concentrations of AA were incubated with 40-50 $\mu \mathrm{g}$ of microsomal protein for $10 \mathrm{~min}$ at $37^{\circ} \mathrm{C}$. In some incubations, microsomes were preincubated with indomethacin before incubation with $\mathrm{AA}$, which completely abolished the response.

removed and various agonists were added for $1 \mathrm{~h}$ (Fig. 3). Actinomycin $\mathrm{D}$ completely abolished the enhanced agonistinduced $\mathrm{PGE}_{2}$ release from MNCF-pretreated fibroblasts. A

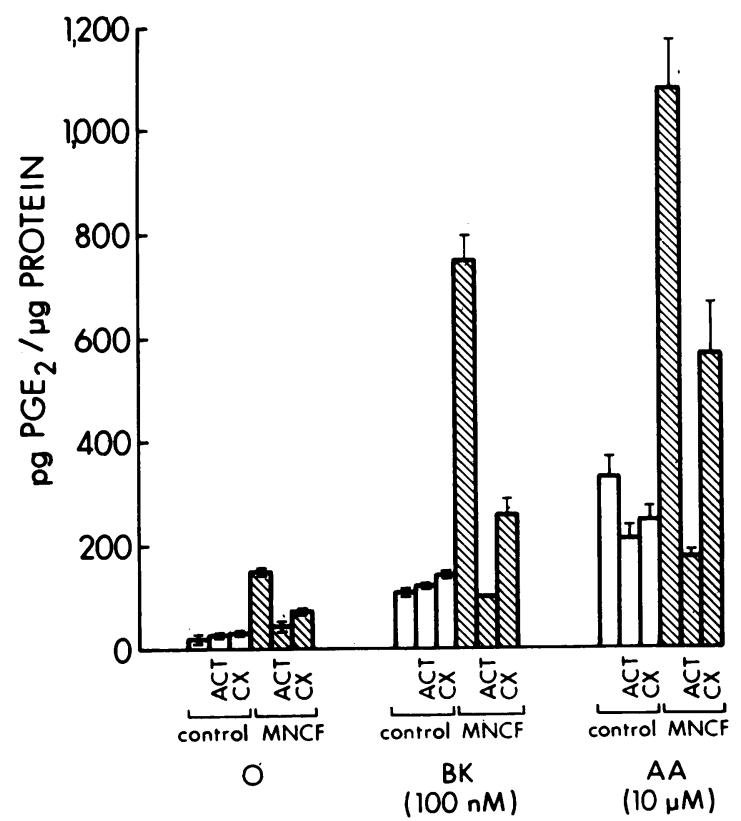

Figure 3. Effect of protein synthesis inhibitors on agonist-induced $\mathrm{PGE}_{2}$ release. Fibroblasts pretreated with $5 \%$ control medium (口) or $5 \%$ MNCF (ם) with and without actinomycin D (ACT; $40 \mathrm{nM}$ ) or cycloheximide $(\mathrm{Cx} ; 36 \mathrm{nM})$ were incubated with bradykinin (100 $\mathrm{nM})$ or $\mathrm{AA}(10 \mu \mathrm{M})$, and $\mathrm{PGE}_{2}$ production was assayed by RIA. All MNCF-treated values are statistically different $(P \leq 0.01)$ from both control treated cultures and MNCF plus protein synthesis inhibitor treated cultures. There is no statistical difference between control or control plus protein synthesis inhibitor cultures. similar result was seen with cycloheximide, although the inhibition was not as complete. Clearly the inhibitors were not acting as nonspecific cyclooxygenase inhibitors, since the control-treated cells had unchanged responses. The inhibition of the facilitated bradykinin and AA-induced fibroblast $\mathrm{PGE}_{2}$ response indicates that these responses were in fact due to new protein synthesis.

Since $\mathrm{PGE}_{2}$ has been shown in some systems to modulate DNA synthesis as determined by thymidine incorporation (22), we wished to determine if the elevated levels of $\mathrm{PGE}_{2}$ induced by MNCF were modulating the enhanced bradykinin and $\mathrm{AA}$ responses. The MNCF-induced $\mathrm{PGE}_{2}$ release was inhibited with ibuprofen (Table I), a readily reversible cyclooxygenase inhibitor. After $48 \mathrm{~h}$, the ibuprofen was washed off the cells, which were then stimulated with various agonists. There was no difference in response to bradykinin or AA for fibroblasts pretreated with MNCF with and without ibuprofen (data not shown).

\section{Discussion}

Our experiments were designed to address the mechanism by which monocyte factors elicit a large basal increase in fibroblast $\mathrm{PGE}_{2}$ release. One of the most striking findings in this study was that MNCF could alter fibroblast response to agoniststimulated $\mathrm{PGE}_{2}$ synthesis. Bradykinin, an autocoid generated at sites of inflammation, induced considerably more $\mathrm{PGE}_{2}$ production from intact cultured fibroblasts pretreated with MNCF than from control-treated fibroblasts. This increase in bradykinin-induced AA metabolism was due to new protein synthesis, and was not affected by the elevated levels of $\mathrm{PGE}_{2}$ during the 48-h pretreatment. MNCF-treated fibroblasts exhibited a protein synthesis-dependent increase, which at least in part accounts for the total $48-\mathrm{h} \mathrm{PGE}_{2}$ accumulation. It is still unclear whether the entire enhanced basal production of $\mathrm{PGE}_{2}$ was due to de novo protein synthesis in cyclooxygenase activity. Although this paper only addresses the mechanism of an agumented cyclooxygenase activity, it is quite likely that MNCF may also enhance $\mathrm{PGE}_{2}$ production by other mechanisms such as $(a)$ an increase in phospholipase activity, $(b)$ a decrease in AA reacylation, or $(c)$ a decrease in PG metabolic activity. The cyclooxygenase activity in MNCF-treated cells is about three times the activity in control treated cells, whereas the magnitude of the bradykinin response in MNCF-treated cells is 10 times that of the control-treated cells. Thus, whether the facilitated bradykinin response is due to just an increase in cyclooxygenase activity, or if in fact the phospholipase activity and/or bradykinin receptor are also altered by MNCF, remains to be established. The MNCF-induced facilitation of the agonist-stimulated $\mathrm{PGE}_{2}$ release from fibroblasts is not specific for bradykinin, since the PDGF response is also enhanced. Platelets are also present at inflammatory or injury sites (23), and could readily interact with mononuclear cells and fibroblasts.

These experiments may help clarify possible interactions of monocytes and fibroblasts at sites of the tissue inflammation. 
The basal increase in $\mathrm{PGE}_{2}$ in fibroblast-like cells in gingivitis (16) or rheumatoid arthritis (15) may be due to the induction of more cyclooxygenase activity by monocytes. The HNK is another model of tissue inflammation characterized by the presence of fibroblasts and macrophages, and has an exaggerated arachidonate metabolic capacity (17). Microsomal studies of cyclooxygenase activity in the cortex of an HNK demonstrated that the $V_{\max }$ increased approximately fourfold with no change in the $K_{\mathrm{m}}$ as compared with the unobstructed contralateral kidney (CLK) (24). Thus, the exaggerated cyclooxygenase activity observed in the cortical microsomes of the HNK may in part reflect the mononuclear cell factor induction of fibroblast cyclooxygenase. Similarly, the facilitated bradykinin-induced $\mathrm{PGE}_{2}$ in the isolated ex-vivo perfused $\mathrm{HNK}$ may reflect monocytes altering the bradykinin response. The heterogeneous HNK cell culture, derived from cortical explants, consisting of macrophages and fibroblasts, had an enhanced release of $\mathrm{PGE}_{2}$ in response to bradykinin or exogenous AA compared with CLK cultures, which only contained fibroblasts (18). Passaged HNK cultures, which only contained fibroblasts, produced much less $\mathrm{PGE}_{2}$ in response to bradykinin and $\mathrm{AA}$, whereas CLK fibroblast responses remained unchanged with passage. Therefore, the mechanism invoked here is that macrophage in the primary HNK co-culture system can modulate the fibroblast cyclooxygenase and bradykinin response, consistent with our current data.

$\mathrm{PGE}_{2}$ is thought to have many functions at a site of inflammation. This study demonstrates the possibility of an amplification scheme to greatly enhance local concentrations of $\mathrm{PGE}_{2}$. Thus, not only mononuclear cells can chronically stimulate fibroblast $\mathrm{PGE}_{2}$, but agonists such as bradykinin, present at the inflammation, can also have a profound impact on fibroblast $\mathrm{PGE}_{2}$ release.

\section{Acknowledgments}

This manuscript was supported by National Institutes of Health training grants GM-07805, HL-14397, and HL-20787.

\section{References}

1. Humes, S. L., R. J. Bonney, L. Pelus, M. E. Dahlgren, S. J. Sadowski, F. A. Kuehl, Jr., and P. Davies. 1977. Macrophage synthesize and release prostaglandins in response to inflammatory stimuli. Nature (Lond.). 269:149-151.

2. Einstein, L. P., E. E. Schneeberger, and H. R. Colten. 1976. Synthesis of the second component of complement by long-term primary cultures of human monocytes. J. Exp. Med. 143:114-126.

3. Gery, I., and B. H. Waksman. 1972. Potentiation of the T-lymphocyte response to mitogens. II. The cellular source of potentiating mediator(s). J. Exp. Med. 136:143-155.

4. Meier, H., J. Pierce, R. Colman, and A. Kaplan. 1977. Activation and function of human Hageman factor. J. Clin. Invest. 60:18-31.

5. Barabe, J., F. Marceau, B. Thieriault, J.-N. Drouin, and D. Regoli. 1979. Cardiovascular actions of kinins in the rabbit. Can. J. Physiol. Pharmacol. 57:78-91.

6. Johnson, A. R. 1970. Effects of kinins on organ systems. Handb. Exp. Pharmacol. 25(Suppl):357-399.
7. Needleman, P., S. L. Key, S. E. Denny, P. C. Isakson, and G. R. Marshall. 1975. The mechanism and modification of bradykinininduced coronary vasodilation. Proc. Natl. Acad. Sci. USA. 72:20602063.

8. Hong, S. L., and L. Levine. 1976. Stimulation of prostaglandin synthesis by bradykinin and thrombin and their mechanism of action on MC5-5 fibroblasts. J. Biol. Chem. 251:5814-5816.

9. Becherer, P. R., L. F. Mertz, and N. L. Baenziger. 1982. Regulation of prostaglandin synthesis mediated by thrombin and B2 bradykinin receptors in a fibrosarcoma cell line. Cell. 30:243-251.

10. Dick, W. C., D. M. Grennan, and I. J. Zeilin. 1976. Studies on relative effects of prostaglandins, bradykinin, 5-hydroxytryptamine, and histamine on synovial microcirculation in dogs. Br. J. Pharmacol. 56:313-316.

11. Grennan, D. M., W. Mitchell, W. Miller, and I. J. Zeilin. 1977. Effects of prostaglandin $E_{1}$, bradykinin, and histamine on canine synovial vascular permeability. Br. J. Pharmacol. 60:251-254.

12. Goodwin, J. S., and J. Ceuppens. 1983. Regulation of the immune response by prostaglandins. J. Clin. Immunol. 3:295-315.

13. Korn, J. H., P. V. Halushka, and E. C. LeRoy. 1980. Mononuclear cell modulation of connective tissue function: suppression of fibroblast growth by stimulation of endogenous prostaglandin production. J. Clin. Invest. 65:543-554.

14. DiSouza, S., D. J. Englis, A. Clark, and R. G. Russell. 1981. Stimulation of production of prostaglandin $\mathrm{E}$ in gingival cells exposed to products of human blood mononuclear cells. J. Biochem. (Tokyo). 198:391-396.

15. Dayer, J.-M., D. R. Robinson, and S. M. Krane. 1977. Prostaglandin production by rheumatic synovial cells: stimulation by a factor from human mononuclear cells. J. Exp. Med. 145:1399-1404.

16. Clark, J. G., K. M. Kostal, and B. A. Marino. 1983. Bleomycininduced pulmonary fibrosis in hamsters. J. Clin. Invest. 72:2082-2091.

17. Okegawa, T., P. Jonas, K. DeSchryver, A. Kawasaki, and P. Needleman. 1983. Metabolic and cellular alterations underlying the exaggerated renal prostaglandin and thromboxane synthesis in ureter obstruction in rabbits: inflammatory response involving fibroblasts and mononuclear cells. J. Clin. Invest. 71:81-90.

18. Jonas, P. E., K. M. Leahy, K. DeSchryver-Kecskemeti, and P. Needleman. 1984. Cellular interactions and exaggerated arachidonic acid metabolism in rabbit renal injury. J. Leuk. Biol. 35:55-64.

19. Böyum, A. 1968. Separation of leukocytes from blood and bone marrow. Scand. J. Clin. Lab. Invest. 21(Suppl. 97):77-89.

20. Reingold, D. F., K. Walters, S. Holmberg, and P. Needleman. 1981. Differential biosynthesis of prostaglandins by hydronephrotic rabbit and cat kidneys. J. Pharmacol. Exp. Ther. 216:510-515.

21. Rosengurt, E., P. Stroobant, M. D. Waterfield, T. F. Deuel, and M. Keehan. 1983. Platelet-derived growth factor elicits cyclic AMP accumulation in Swiss 3T3 cells: role of prostaglandin production. Cell. 34:265-272.

22. Otto, A. M., M. Nilsen-Hamilton, B. D. Boss, M.-O. Ulrich, and $L$. Jimenez DeAsua. 1982. Prostaglandins $E_{1}$ and $E_{2}$ interact with prostaglandin $F_{2 \alpha}$ to regulate initiation of DNA replication and cell division in Swiss 3T3 cells. Proc. Natl. Acad. Sci. USA. 79:4992-4996.

23. Nachman, R. L., and B. B. Weksler. 1980. The platelet as an inflammatory cell. In The Cell Biology of Inflammation. G. Weissman, editor. Elsevier/North Holland, Amsterdam. 145-162.

24. Wu, Y. S., T. Lysz, A. Wyche, and P. Needleman. 1983. Kinetic comparison and regulation of the cascade of microsomal enzymes in renal arachidonate and endoperoxide metabolism. J. Biol. Chem. 258:2188-2192. 